\title{
Effects of supplementation of sepiolite and humate to beef cattle concentrate on pellet quality characteristics
}

\author{
Sakine YALÇIN ${ }^{1, a, \bowtie}$, Tuğba KARAKAN ${ }^{1, b}$, Muhammad Shazaib RAMAY $^{1, c}$, İsmail SARICAN ${ }^{2, d}$ \\ ${ }^{1}$ Ankara University, Faculty of Veterinary Medicine, Department of Animal Nutrition and Nutritional Diseases, Ankara; \\ ${ }^{2}$ Kamer Feed Manufacturing and Marketing Company, Ereğli, Konya, Turkey.

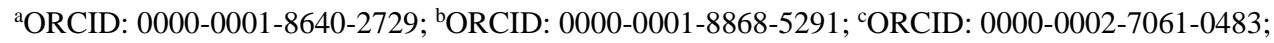 \\ dORCID: 0000-0002-2289-7483

Corresponding author: sayalcin @ ankara.edu.tr
Received date: 04.08.2019- Accepted date: 22.10.2019

\begin{abstract}
The aim of this study was to evaluate some pelleting characteristics of beef cattle concentrate with added sepiolite and potassium humate alone or combined. For this purpose, one control group (basal concentrate) with no additive and five treatment groups with $1 \%$ sepiolite $(\mathrm{S}), 0.25 \%$ potassium humate $(\mathrm{H}-25), 0.50 \%$ potassium humate $(\mathrm{H}-50), 1 \%$ sepiolite $+0.25 \%$ potassium humate (SH-25) and $1 \%$ sepiolite $+0.50 \%$ potassium humate (SH-50) added as top-dressed into mixer were used. For each experimental group, a total of 36 tons of pellet concentrates were produced in six batches with 6 tons per batch. The basal pelleted concentrate included $90.29 \%$ dry matter, $14.51 \%$ crude protein, $11.76 \%$ crude fibre and $3.14 \%$ ether extract. Results showed that adding sepiolite up to $1 \%$ in beef cattle concentrate as top-dressed in mixer reduced moisture losses and improved the durability of pelleted feed. Sepiolite addition also lowered pellet water activity during storage. Adding potassium humate alone up to $0.50 \%$ was not enough to improve the pellet quality in terms of durability or water activity. Potassium humate supplementation alone or with sepiolite presented with lower moisture losses than control, and it was more evident during storage. In conclusion, the use of sepiolite in beef cattle concentrates as pellet binder seemed to be providing more durable feed pellets with lower water activity. Promising results were obtained from both the supplements in limiting the moisture losses post- pelleting and storage. Regarding the role of potassium humate as pellet binder in animal feed industry further research is needed.
\end{abstract}

Keywords: Beef cattle, concentrate feed, pellet quality, potassium humate, sepiolite.

\section{Besi sığırı konsantre yemlerine sepiyolit ve humat ilavesinin pelet kalite özellikleri üzerine etkileri}

Özet: Bu araştırmanın amacı, besi sığııı yemlerinde sepiyolit ve potasyum humatın tek başlarına ve birlikte kullanımının pelet kalite özelliklerine olan etkilerini belirlemektir. Araştırmada katkı yapılmayan kontrol grubu yemi (bazal kesif yem) ve beş deneme grubu yemi hazırlanmıştır. Deneme grup yemlerini oluşturmak için bazal yemin üzerine karış̧ıııııda sırasıyla \%1 sepiyolit (S), \%0,25 potasyum humat $(\mathrm{H}-25), \% 0,50$ potasyum humat $(\mathrm{H}-50), \% 1$ sepiyolit $+\% 0,25$ potasyum humat $(\mathrm{SH}-25)$ ve $\% 1$ sepiyolit $+\% 0,50$ potasyum humat (SH-50) katılmıştır. Denemedeki grupların her biri için altı kez altışar tonluk pelet yem üretimi yapılmıştır. Dolayısıyla her bir grup için toplam da 36 ton pelet yem üretilmiştir. Peletlemede kullanılan besi sığırı kontrol yemi \%90,29 kuru madde, \%14,51 ham protein, \%11,76 ham selüloz ve \%3,14 ham yağ içermektedir. Sonuçlar besi sığırı konsantre yemlerine \%1'e kadar sepiyolit eklenmesinin nem kayıplarını azalttı̆ı̆ın ve pelet dayanıklılık indeksi değerlerini iyileştirdiğini göstermiş̧tir. Ayrıca sepiyolitin eklenmesi depolanma sırasında pelet su aktivitesini azaltmıștı. Potasyum humatın yemlere tek başına $\% 0,50$ 'ye kadar katılmasi; pelet dayanıklılığı ve su aktivitesini iyileştirmesi açısından yeterli olmamıştır. Potasyum humatın tek başına veya sepiyolit ile birlikte kullanılması özellikle depolama süresince kontrol grubu yemine kıyasla nem kaybının daha düşük olmasını sağlamıştır. Bu nedenle besi sığırı konsantre yemlerine sepiyolitin pelet bağlayıcı olarak katılmasının düşük su aktivitesine sahip daha dayanıklı pelet yemin üretiminde etkili olacağı sonucuna varılmıştır. Her iki yem katkısının pelet üretim süresince ve pelet depolama esnasında su kaybını azaltması da çalışmanın önemli sonuçlarındandır. Yem sanayisinde potasyum humatın pelet bağlayıcı olarak kullanımının daha iyi belirlenebilmesi için çalışmalar yapılmalıdır.

Anahtar sözcükler: Besi sığırı, kesif yem, pelet kalitesi, potasyum humat, sepiyolit.

\section{Introduction}

Pelleting was first introduced into the feed industry in the 1920s (24) and since that time its usage has increased and improved steadily. Nowadays the pelleting process, due to its physical and nutritional benefits, is widely used in commercial feed production. The potential 
physical benefits involve improved ease of handling, reduced ingredient segregation, less feed wastage, and increased bulk density whereas the improved animal performance and increased animal products with higher quality are one of the well-known nutritional benefits of feeding pelleted feed. The improvements in animal performance with the feeding of pelleted feed have been attributed to many factors such as better feed utilization, destruction of pathogenic microorganisms, thermal modification of starch \& protein and enhanced palatability (8). All these modifications in feed characteristics make the pellet quality a high priority for the feed manufacturers.

The physical form (mash or pelleted) in which the concentrate feeds are fed to the cattle is of great importance. Bertipaglia et al. (10) proposed three possible characteristics by which the pelleted concentrates may affect rumen fermentation in intensively reared beef cattle. The first two pelleting features favor the fermentation process via a reduction in the particle size and starch gelatinization, however, the third feature involving the compactness and hardness of pelleted feed would reduce its breakdown, thus counterbalancing the former effect and delaying the fermentation process (10). A lot of efforts have been made to improve this compactness of the pelleted feed without compromising its quality.

The pellet durability index (PDI) is frequently used as a predictor of pellet fines produced during production and mechanical handling of feed pellets. Fines in the feeders result in feed wastage, animal refusals and increased management (9). Several factors including type of feed materials, their proportions, nutrient content (especially fat, fibre and minerals), particle size, presence of binders and factors related to the pelleting process such as conditioning, the distance between the roller and die, hole compression etc. affect PDI value of feeds $(3,11,16$, 22,28 ). The addition of high levels of fats before pelleting process results in decreased pellet quality, however, the addition of protein and fibrous ingredients improves pellet quality $(9,19,23)$. Other than these factors, a lot of alternative feed additives such as sepiolite, bentonite, carboxymethylcellulose, and lignosulfonates have been investigated for their role in improving the pellet quality (21).

Sepiolite is a hydrated magnesium silicate. It can be used as a binder and an anti-caking agent up to $2 \%$ in feeds for different animal species (13). Sepiolite reduces dust losses and increases pellet durability and quality $(30,32,34)$.

Potassium humate, the potassium salt of humic acid, is commercially produced from leonardite, an oxidation product of lignite coal. Leonardite has a high humic acid content compared with other organic materials $(2,6,14)$. They are colloidal substances and act as clay (1). Humic acid has a chemically heterogeneous structure which includes functional groups such as carboxyl $(\mathrm{COOH})$, hydroxyl $(\mathrm{OH})$ and amine (NH2). By replacing hydrogen ions in carboxyl and hydroxyl groups with metal ions or chemically cross-linking, humic acid is rendered insoluble in water and can be used in different areas (2). It improves water retention properties of the soil, as well as prevents bacterial and fungal growth, thus reducing the level of mycotoxin in the feed.

To best of our knowledge, no published data is available investigating the pelletizing of beef cattle concentrate with added potassium humate alone or combined with sepiolite. The present study, therefore, was proposed to evaluate some pelleting characteristics of beef cattle concentrate with added sepiolite and potassium humate alone or combined.

\section{Material and Methods}

A commercial concentrate for the beef cattle was used in this study and pellet feeds were produced in a commercial feed factory in Turkey. The concentrate comprised mainly wheat bran $(350 \mathrm{~kg} / \mathrm{t})$, barley $(100 \mathrm{~kg} / \mathrm{t})$, wheat $(100 \mathrm{~kg} / \mathrm{t})$, corn $(100 \mathrm{~kg} / \mathrm{t})$, sunflower seed meal $(70$ $\mathrm{kg} / \mathrm{t})$, lentil bran $(70 \mathrm{~kg} / \mathrm{t})$ and molasses $(35 \mathrm{~kg} / \mathrm{t})$. The present study consisted of a total of six experimental groups; a control group with no added sepiolite or potassium humate in the basal diet, and five treatment groups having $1 \%$ sepiolite $(\mathrm{S}), 0.25 \%$ potassium humate $(\mathrm{H}-25), 0.50 \%$ potassium humate $(\mathrm{H}-50), 1 \%$ sepiolite + $0.25 \%$ potassium humate $(\mathrm{SH}-25)$ and $1 \%$ sepiolite + $0.50 \%$ potassium humate ( $\mathrm{SH}-50)$ in the basal diet added as top-dressed into the mixer. Before addition to the basal diet, potassium humate was first mixed in water in a ratio of 1:1. The potassium humate (TKİ Hümas-Turkey) used in this study was produced from leonardite reserves in Turkey. It consisted of 5\% organic matter (w/w), 12\% humic acid + fulvic acid, 3\% water-soluble potassium oxide and had a pH between 11 and 13 (27). The sepiolite (Exal T, Tolsa-Turkey) used consisted of $73 \%$ clay minerals (65\% sepiolite), $21 \%$ dolomite and $6 \%$ calcite as reported by Yalçın et al. (32).

Mixer capacity of the feed mill was 2 tons. For each experimental group, a total of 36 tons of pellet concentrates were produced in six batches with 6 tons per batch. The disc used was $5 \mathrm{~mm}$ in diameter and $60 \mathrm{~mm}$ in hole length. The parameters for the pellet manufacturing process are presented in Table 1.

During each production batch, the feed samples (for every mill run; 2 tons/run) were taken from the mixer blend, post-conditioning \& post-pelleting (cooled pellets), and later subjected to the moisture analysis (5). Moisture losses between the feed blend in the mixer and pelleted feed after cooling were also calculated. Additionally, for all the production batches, pelleted feed samples from the control group were analyzed for crude protein, crude fibre, ether extract, ash and starch (5) as well as for NDF and ADF values (17). 
Table 1. Some production parameters for pelleting process.

\begin{tabular}{lcccccc}
\hline \multirow{2}{*}{ Parameters } & \multirow{2}{*}{ Control group } & \multicolumn{5}{c}{ Treatment groups } \\
\cline { 3 - 7 } & & $\mathbf{S}$ & H-25 & H-50 & SH-25 & SH-50 \\
\hline Production, t & 36 & 36 & 36 & 36 & 36 & 36 \\
Mixer capacity, t & 2 & 2 & 2 & 2 & 2 & 2 \\
Disc hole diameter, mm & 5 & 5 & 5 & 5 & 5 & 5 \\
Disc hole length, mm & 60 & 60 & 60 & 60 & 60 & 60 \\
Sepiolite addition $(\%)$ & - & 1 & - & - & 1 & 1 \\
Potassium humate addition $(\%)$ & - & - & 0.25 & 0.50 & 0.25 & 0.50 \\
\hline
\end{tabular}

S: $1 \%$ sepiolite; $\mathrm{H}-25$ : $0.25 \%$ potassium humate; $\mathrm{H}-50$ : $0.50 \%$ potassium humate; $\mathrm{SH}-25: 1 \%$ sepiolite and $0.25 \%$ potassium humate; SH-50: $1 \%$ sepiolite and $0.50 \%$ potassium humate.

The PDI values for the pelleted feed after cooling were measured with a Pfost Box equipment using the sieve with a hole diameter of $4 \mathrm{~mm}$ (7). Four measurements were made for each feed sample. The water activity values of all the mash and pelleted feed samples collected were measured using LabSwift-aw (Novasina) water activity device. Furthermore, the pelleted feeds were stored in 50 $\mathrm{kg}$ bags at room temperature for 20 days, and later, their moisture content and water activity level were determined as described above. Moisture losses between post-pellet and post storage were also calculated.

Statistical analysis was conducted using the ANOVA procedure of the SPSS 23.0 (SPSS Inc., Chicago, IL, USA). The experimental unit was 18 (6 batches with 3 samples each). The normality of data distribution was tested using the Kolmogorov-Smirnov test. One-way ANOVA was performed to examine the differences among groups. The significance of mean differences among groups was tested by the Tukey test. A value of $\mathrm{P}<0.05$ was considered statistically significant (12).

\section{Results}

The average nutrient composition of the pelleted basal beef cattle concentrate is presented in Table 2 . Effects of addition of sepiolite and potassium humate on moisture content, moisture losses and PDI values of concentrate feeds are shown in Table 3. No significant differences were observed among experimental groups for the moisture content of concentrate feed-blends in the mixer, however, post-conditioning, the moisture content of the SH-50 feed group was significantly higher than that of other groups $(\mathrm{P}<0.001)$. Post-pelleting, the moisture loss in the $\mathrm{H}-25$ group was lowest among all groups $(\mathrm{P}<0.001)$. PDI values for the $\mathrm{S}, \mathrm{SH}-25, \mathrm{SH}-50$ feed groups were significantly higher $(\mathrm{P}=0.002)$ when compared to the control group as well as $\mathrm{H}-25$ and $\mathrm{H}-50$ feed groups.

Table 2. Nutrient composition of the pelleted basal concentrates (mean \pm standard error).

\begin{tabular}{lc}
\hline Nutrient & $\%$ \\
\hline Dry matter & $90.29 \pm 0.38$ \\
Ether extract & $3.14 \pm 0.08$ \\
Crude protein & $14.51 \pm 0.15$ \\
Crude fibre & $11.76 \pm 0.12$ \\
Ash & $6.24 \pm 0.28$ \\
Starch & $24.36 \pm 0.41$ \\
NDF & $28.35 \pm 0.44$ \\
ADF & $14.04 \pm 0.41$ \\
\hline
\end{tabular}

Table 3. Moisture content and moisture losses of concentrate feeds during pellet production and PDI values of pelleted concentrates.

\begin{tabular}{|c|c|c|c|c|c|}
\hline \multirow{2}{*}{ Group } & \multicolumn{3}{|c|}{ Moisture content (\%) } & \multirow{2}{*}{$\begin{array}{c}\text { Moisture loss (\%) } \\
\text { Mixer to Post-pelleting }\end{array}$} & \multirow{2}{*}{ PDI (\%) } \\
\hline & Mixer blend & Post-conditioning & Post-pelleting & & \\
\hline Control & 11.14 & $13.10^{\mathrm{b}}$ & $10.02^{\mathrm{b}}$ & $10.05^{\mathrm{a}}$ & $94.65^{\mathrm{b}}$ \\
\hline S & 11.06 & $13.44^{\mathrm{b}}$ & $10.49^{\mathrm{a}}$ & $5.15^{\mathrm{cd}}$ & $95.57^{\mathrm{a}}$ \\
\hline $\mathrm{H}-25$ & 11.14 & $13.15^{\mathrm{b}}$ & $10.69^{\mathrm{a}}$ & $4.04^{\mathrm{d}}$ & $93.90^{\mathrm{b}}$ \\
\hline $\mathrm{H}-50$ & 11.56 & $13.32^{\mathrm{b}}$ & $10.60^{\mathrm{a}}$ & $8.30^{\mathrm{ab}}$ & $93.65^{\mathrm{b}}$ \\
\hline SH-25 & 11.38 & $13.29^{b}$ & $10.49^{\mathrm{a}}$ & $7.82^{\mathrm{ab}}$ & $94.95^{\mathrm{a}}$ \\
\hline SH-50 & 11.26 & $14.04^{\mathrm{a}}$ & $10.48^{\mathrm{a}}$ & $6.93^{\mathrm{bc}}$ & $95.32^{\mathrm{a}}$ \\
\hline SEM & 0.052 & 0.067 & 0.056 & 0.319 & 0.166 \\
\hline $\mathrm{P}$ & 0.074 & $<0.001$ & 0.003 & $<0.001$ & 0.002 \\
\hline
\end{tabular}

a,b,c,d: Means within a column followed by different letters differ significantly $(\mathrm{P}<0.05)$; $\mathrm{S}: 1 \%$ sepiolite; $\mathrm{H}-25$ : $0.25 \%$ potassium humate; $\mathrm{H}-50: 0.50 \%$ potassium humate; $\mathrm{SH}-25: 1 \%$ sepiolite and $0.25 \%$ potassium humate; $\mathrm{SH}-50: 1 \%$ sepiolite and $0.50 \%$ potassium humate; SEM: Pooled standard error of mean; PDI: Pellet durability index. 
Table 4. Moisture content and total moisture losses of pelleted concentrate after storage.

\begin{tabular}{lcc}
\hline \multirow{2}{*}{ Group } & Moisture content $(\%)$ & Moisture loss $(\%)$ \\
\cline { 2 - 3 } & Post-storage & Post-pellet to Post-storage \\
\hline Control & $9.42^{\mathrm{b}}$ & $5.99^{\mathrm{a}}$ \\
S & $10.28^{\mathrm{a}}$ & $2.00^{\mathrm{b}}$ \\
H-25 & $10.34^{\mathrm{a}}$ & $3.27^{\mathrm{b}}$ \\
H-50 & $10.24^{\mathrm{a}}$ & $3.40^{\mathrm{b}}$ \\
SH-25 & $10.16^{\mathrm{a}}$ & $3.15^{\mathrm{b}}$ \\
SH-50 & $10.26^{\mathrm{a}}$ & $2.10^{\mathrm{b}}$ \\
SEM & 0.073 & 0.313 \\
P & $<0.001$ & $<0.001$ \\
\hline
\end{tabular}

a,b: Means within a column followed by different letters differ significantly $(\mathrm{P}<0.05)$; S: $1 \%$ sepiolite; H-25: 0.25\% potassium humate; H-50: $0.50 \%$ potassium humate; SH-25: $1 \%$ sepiolite and $0.25 \%$ potassium humate; $\mathrm{SH}-50: 1 \%$ sepiolite and $0.50 \%$ potassium humate; SEM: Pooled standard error of mean.

Table 5. Water activity levels of mash/pelleted concentrates.

\begin{tabular}{lcccc}
\hline \multirow{2}{*}{ Group } & \multicolumn{3}{c}{ Water Activity } \\
\cline { 2 - 5 } & Mixer blend & Post-conditioning & Post-pelleting & Post-storage \\
\hline Control & $0.60^{\mathrm{ab}}$ & $0.66^{\mathrm{b}}$ & $0.54^{\mathrm{b}}$ & $0.61^{\mathrm{a}}$ \\
S & $0.58^{\mathrm{b}}$ & $0.66^{\mathrm{b}}$ & $0.54^{\mathrm{b}}$ & $0.56^{\mathrm{b}}$ \\
$\mathrm{H}-25$ & $0.61^{\mathrm{ab}}$ & $0.66^{\mathrm{b}}$ & $0.57^{\mathrm{ab}}$ & $0.59^{\mathrm{ab}}$ \\
$\mathrm{H}-50$ & $0.63^{\mathrm{a}}$ & $0.67^{\mathrm{b}}$ & $0.59^{\mathrm{a}}$ & $0.62^{\mathrm{a}}$ \\
SH-25 & $0.64^{\mathrm{a}}$ & $0.68^{\mathrm{ab}}$ & $0.58^{\mathrm{a}}$ & $0.60^{\mathrm{a}}$ \\
SH-50 & $0.62^{\mathrm{ab}}$ & $0.70^{\mathrm{a}}$ & $0.59^{\mathrm{a}}$ & $0.61^{\mathrm{a}}$ \\
SEM & 0.004 & 0.003 & 0.004 & 0.005 \\
P & 0.003 & 0.002 & $<0.001$ & $<0.001$ \\
\hline
\end{tabular}

a,b: Means within a column followed by different letters differ significantly $(\mathrm{P}<0.05) ; \mathrm{S}: 1 \%$ sepiolite; $\mathrm{H}-25: 0.25 \%$ potassium humate; H-50: $0.50 \%$ potassium humate; SH-25: $1 \%$ sepiolite and $0.25 \%$ potassium humate; SH-50: $1 \%$ sepiolite and $0.50 \%$ potassium humate; SEM: Pooled standard error of mean.

The moisture content of pelleted feeds after 20 days of storage along with the moisture losses between postpellet and post-storage period is shown in Table 4. After 20 days, the moisture loss in the control group was highest than all supplemented groups $(\mathrm{P}<0.001)$.

Effects of usage of sepiolite and humate in beef cattle concentrate on water activity levels (\%) at a temperature of $22-24^{\circ} \mathrm{C}$ are shown in Table 5. In the mixer, the water activity levels of concentrate feed supplemented with sepiolite or/and humate didn't differ significantly from that of the control group. However, when compared to the control group the SH-50 feed group post-conditioning $(\mathrm{P}=0.002)$ whereas $\mathrm{H}-50, \mathrm{SH}-25$ and $\mathrm{SH}-50$ feed groups post-pelleting $(\mathrm{P}<0.001)$ presented with significantly higher water activity values. Post-storage, feed group with added sepiolite $(\mathrm{S})$ only presented with the lowest water activity $(\mathrm{P}<0.001)$ when compared to others.

\section{Discussion and Conclusion}

Feeding pelleted feed alone may not be enough to ensure improved animal performance; therefore, pellet quality should always be considered for better results.
Pellet quality is affected by many factors such as diet formulation, feed composition, ingredient particle size, the inclusion of binder additives and pelleting conditions. Considering the importance of binders in pellet production, the objective of this study was to evaluate the pellet quality of beef cattle concentrate with added sepiolite and potassium humate alone or combined.

In the present study, all the experimental runs were completed with the same production parameters including diet formulation, amounts of pellets produced, mixer capacity, disc hole diameter, and disc hole length. As both the feed additives are considered of no nutritive value, therefore, the pelleted feed samples from the control group only were subjected to the compositional analysis. The crude protein, ether extract and crude fiber contents of the pelleted basal beef cattle concentrate were 14.51, 3.14 and $11.76 \%$, respectively.

The moisture content of the mash feed pre- and postconditioning is a very important factor affecting the pellet quality as well as production efficiency. Stable moisture content post-pelleting is also important especially from manufacturer's point of view, concerning economic 
consequences with the total loss in weight in the finished product between packing and delivery to the customers. Results from the present study indicated that postconditioning the moisture retention in the feed group added with $1 \%$ sepiolite and $0.50 \%$ potassium humate (SH-50) was highest among all experimental groups $(\mathrm{P}<0.001)$. Although non-significant data also suggested a relatively small increase in the moisture level of other treatment groups post-conditioning when compared to the control group. Furthermore, among experimental groups, the control group presented with the highest moisture loss from mixer blend to post-pelleting. The moisture losses of $\mathrm{S}, \mathrm{H}-25$ and $\mathrm{SH}-50$ feed groups were significantly lower than that of control group feed $(\mathrm{P}<0.001)$. Considering the statistically non-different moisture level of all feed blends in mixer and similar conditioning environment, it can be inferred that addition of sepiolite or potassium humate alone or combined might have increased the porosity and water absorption capacity of the feed mash postconditioning, which ultimately rendered in lower moisture losses in these feed groups post-pelleting. In accordance with this view, Yalçın et al. (32) also reported a linear increase in the moisture content of the dairy concentrate post-conditioning as well as post-pelleting when supplemented with increasing doses of sepiolite. In another study, also with dairy cattle concentrate added with 1\% sepiolite, Yalçın et al. (33) found a marked rise in feed moisture level post-conditioning and postpelleting. For potassium humate, no scientific study was available determining its role in quality pellet feed production. Griban et al. (18) reported that humic acid can improve the water retention and water holding capacity of materials. Data on moisture losses, especially poststorage, showed that addition of sepiolite and potassium humate alone or combined significantly reduced moisture losses as compared to the control group $(\mathrm{P}<0.001)$. Sepiolite alone resulted in the lowest storage losses in terms of moisture $(2 \%)$

A reduction in fine particles is beneficial in terms of feed losses, animal performance and the farmer profit (30). In the present study, pellet durability results were lower for potassium humate alone either 0.25 or $0.50 \%$, however, when added with sepiolite it significantly improved the PDI values than that of the control group. Sepiolite alone topped the PDI test among all groups. High temperature and moisture levels are very critical in the activation of natural binders in the material including protein and starch, thus, improving the pellet quality (15, 26). In this study, more moisture retention postconditioning and possible higher heat of friction by sepiolite particles at the die might be reasons for better pellet quality. Other studies also reported improvement in PDI values of pelleted feeds with sepiolite addition $(3,4$, 29-33).
Potassium humate had not been tested before in animal diets for its binding properties. In this study, no positive effect of potassium humate addition was observed on pellet PDI values when compared to the control group, however, in iron ore pelletization humic acid has been reported to have promising results as a binder $(20,35)$. The different raw materials to be pelleted might be the reason for such results.

Water activity level serves as an indicator of the volume of free water. The higher the free water present, the better the conditions for unwanted mould development. A water activity level of 0.65 is often referred to as the limit for safe storage of foods, below which microbiological growth is unlikely to occur (25). In the present study, no explicit effects on water activity were observed when concentrate feeds were supplemented with different additives either alone or combined. Although data showed that sepiolite addition alone might be beneficial in reducing the water activity during storage, it is difficult to conclude that whether the addition of sepiolite or potassium humate were or were not effective in limiting water activity. In an experiment, Yalçın et al. (33) reported no significant difference between water activity values of pelleted concentrates of dairy cattle either from control or sepiolite added group.

The overall conclusion from the present study was that adding sepiolite up to $1 \%$ in the beef cattle concentrate as top-dressed in mixer could help in reducing the moisture losses and improving the PDI values thus enhancing the pellet quality. Sepiolite addition also lowered the pellet deterioration and water activity during storage. On the other hand, the addition of potassium humate $(0.25$ and $0.50 \%)$ alone was not enough to improve the pellet quality in terms of PDI or water activity. However, for moisture losses especially during storage, humate supplemented groups either alone or with sepiolite presented with lower moisture losses than the control group. Further research is needed in evaluating the role of potassium humate as a pellet binder in the animal feed industry.

\section{Acknowledgements}

This research was conducted as a part of the project supported by TUBITAK-TEYDEB (3141012).

\section{Conflict of Interest}

The authors declared that there is no conflict of interest.

\section{References}

1. Aladaş A (2013): Koyunlarda kirkım öncesi C vitamini ve humik asit uygulamasinin kırkım stresini azaltmasındaki etkisinin incelenmesi. Yüksek Lisans Tezi. Afyon Kocatepe Üniversitesi Sağlık Bilimleri Enstitüsü, Afyonkarahisar. 
2. Alpay Ş (2013): Hümik asit esaslı adsorban maddelerle ă̆ır metal giderimi. Yüksek Lisans Tezi. Gazi Üniversitesi Fen Bilimleri Enstitüsü, Ankara.

3. Angulo E, Brufau J, Esteve-Garcia E (1995): Effect of sepiolite on pellet durability in feeds differing in fat and fibre content. Anim Feed Sci Technol, 53, 233-241.

4. Angulo E, Brufau J, Esteve-Garcia E (1996): Effect of a sepiolite product on pellet durability in pig diets differing in particle size and in broiler starter and finisher diets. Anim Feed Sci Technol, 63, 25-34.

5. AOAC (2000): Official Methods of Analysis of the Association of Official Analytical Chemists. 17th ed. AOAC International, Maryland, USA.

6. Ayan S, Sıvacioğlu A, Öner N, et al (2007): Kurak ve yarı kurak alanlarda bitki canlılığını korumada kullanılabilecek toprak islah edici materyaller. 183-190. In: Proceedings of Türkiye'de Yarı Kurak Bölgelerde Yapılan Ağaçlandırma ve Erozyon Kontrolü Uygulamalarının Değerlendirilmesi. Nevşehir, Turkey.

7. Başer Ö, Yalçın S (2017): Determination of some quality characteristics in pet foods. Ankara Univ Vet Fak Derg, 64, 21-24.

8. Behnke KC (1994): Factors affecting pellet quality. 44-54. In: Proceedings of Maryland Nutrition Conference. College Park, USA.

9. Behnke KC (2001): Factors influencing pellet quality. Feed Tech, 5, 19-22.

10. Bertipaglia LMA, Fondevila M, Van Laar H, et al (2010): Effect of pelleting and pellet size of a concentrate for intensively reared beef cattle on in vitro fermentation by two different approaches. Anim Feed Sci Technol, 159, 8895.

11. Bobohm KF (1992): Adjustable roll gap. Benefits to energy demand throughout and pellet durability. Feed International, 13, 30-35.

12. Dawson B, Trapp RG (2001): Basic \& Clinical Biostatistics. Lange Medical Book/ McGraw-Hill Medical Publishing Division, New York.

13. EFSA (2013): Scientific opinion on the safety and efficacy of a preparation of bentonite and sepiolite (Toxfin Dry) as feed additive for all species. EFSA J, 11, 3179.

14. Engin VT, Cöcen EI (2012): Leonardit ve humik maddeler. MT Bilimsel, 1, 13-20.

15. Fairchild F, Greer D (1999): Pelleting with precise mixer moisture control. Feed International, 20, 32-36.

16. Gill C (1993): Chemistry for high quality pellets. Or refining the role of binders. Feed International, 14, 10-11.

17. Goering H, Van Soest P (1970): Forage Fiber Analyses (Apparatus, Reagents, Procedures, and Some Applications). U.S. Agricultural Research Service, Washington DC.

18. Griban VG, Stepchenko LM, Zhorina LV (1988): The live weight gain and disease resistance of young cattle and poultry stock as influenced by physiologically active peat preparation. 45-50. In: Proceedings of $8^{\text {th }}$ International Peat Congress. Leningrad, Russia.
19. McKee JW (1988): Effect of wheat gluten on underwater pellet stability of pelleted catfish and shrimp diets. A Master's Thesis. Kansas State University, Manhattan.

20. Qiu GZ, Jiang T, Li HX, et al (2003): Functions and molecular structure of organic binders for iron ore pelletization. Colloid Surf A Physicochem Eng Asp, 224, 11-22.

21. Rakic L (2012): Feed structure: Effects on physical quality of the feed, chemical status of the feed and nutriional consequence. A Master's Thesis. Norwegian University of Life Science, Norway.

22. Reece FN, Lott BD, Deaton JW (1986): Effects of environmental temperature and corn particle size on response of broilers to pelleted feed. Poult Sci, 65, 636-641.

23. Richardson W, Day EJ (1976): Effect of varying levels of added fat in broiler diets on pellet quality. Feedstuffs, 48, 24.

24. Schoeff RW (1994): History of the Formula Feed Industry. 2-11. In: RR McEllhiney (Ed), Feed Manufacturing Technology IV. American Feed Industry Association, Arlington, Virginia, USA.

25. Shi Y, Parker DB, Cole NA, et al (2001): Surface amendments to minimize ammonia emissions from beef cattle feedlots. Amer Soc Agric Eng, 44, 677-682.

26. Thomas M, Van Vliet T, Van der Poel AFB (1998): Physical quality of pelleted animal feed. 3. Contribution of feedstuff components. Anim Feed Sci Technol, 70, 59-78.

27. TKI-Humas (2016): TKİ-Hümas, Türkiye Kömür İşletmeleri Kurumu Genel Müdürlüğü Arge Dairesi Başkanlığı. Available at www.tkihumas.gov.tr. (Accessed June 12, 2019).

28. Wood JF (1987): The functional properties of feed raw materials and their effect on the production and quality of feed pellets. Anim Feed Sci Technol, 18, 1-17.

29. Yalçın S, Yalçın S, Gebeş ES, et al (2017): Sepiolite as a feed supplement for broilers. Appl Clay Sci, 148, 95-102.

30. Yalçın S, Çıvracı S, Burçak E, et al (2018a): Effects of usage of sepiolite in layer diet on pellet quality and pellet production parameters. Kocatepe Vet J, 11, 134-139.

31. Yalçın S, Onbaşılar I, Escribano F, et al (2018b): Broyler büyütme yeminde sepiyolitin su ile birlikte kullanımının pelet kalitesi ve üretim parametreleri üzerine etkisi. Vet Hekim Der Derg, 89, 25-31.

32. Yalçın S, Burçak E, Onbaşılar İ, et al (2019a): Improvement in pellet production parameters and pellet quality characteristics with sepiolite supplementation in dairy cattle concentrate. Kafkas Univ Vet Fak Derg, 25, 119-123.

33. Yalçın S, Burçak E, Onbaşılar İ, et al (2019b): Effects of sepiolite supplementation to dairy concentrate on pellet quality characteristics. JOAAT, 6, 119-123.

34. Yörük MA, Laçin E, Hayırlı A, et al (2008): Humat ve prebiyotiklerin farkl yerleşim sıklı̆̆ında yetiştirilen Japon bıldircinlarında verim özellikleri, yumurta kalitesi ve kan parametrelerine etkisi. YYÜ Vet Fak Derg, 19, 15-22.

35. Zhou Y, Kawatra SK (2017): Pelletization using humic substance-based binder. Min Proc Ext Met Rev, 38, 83-91. 